\title{
鳳凰殿の形態とその成立要因について THE FACTORS SURROUNDING THE FORM OF THE HŌ-Ō-DEN IN THE WORLD'S COLUMBIAN EXPOSITION IN CHICAGO, 1893
}

\author{
三島 雅 博* \\ Masahiro MISHIMA
}

\begin{abstract}
The Japanese pavilion named Hō-ō-Den was set up in the exposition in Chicago, 1893 and modeled on the holy edifice, Hō-ō-Dō (Phoenix Hall) erected about 1052 at Uji near Kyoto. It consisted of three buildings showing each different artistic periods to represent the history of Japanese art. Though it didn't represent the essence of Japanese architecture and art ideally because of political intention and restriction on program, it showed Japanese beauty of her historial architecture and art in the limitation as a pavilion in the exposition.
\end{abstract}

This paper reports on the factors surrounding the form of the Hō-ō-Den.

Keywords : Hōo-den, Kakuzo Okakura, exposition, Japanses-style, Ryüichi Kuki, Japanese art 鳳凰殿, 岡倉天心, 万国博, 伝統的日本建築, 九鬼隆一, 日本美術

\section{I. はじめに}

鳳凰殿は, 明治 26 年 (1893) にシカゴで開催された 万国博（以下「シカゴ博」と呼ぶ）の日本館で, 鳳凰堂 をモデルとして久留正道が設計し，平安中期・室町・江 戸の各々の時代”を表現した三棟の建物からなる。また， 建設に関係した重要人物としては, 久留以外にもシカゴ 博へ参加するために組織された臨時博覧会事務局（以下 「事務局」と呼ぶ）副総裁九鬼隆一, 同事務官山高信離, 同評議員岡倉覚三（天心）らが特筆される。

建設の経稦については前稿で報告したが2), 本稿では その形態が決定されてゆく過程を探り，モデルに鳳凰堂 が選ばれたことや，表現された三時代が平安中期・室 町・江戸となった理由について論じたい。

鳳凰殿の形態形成には, 後で述べるように政治的な要 因などが大きく関係していた。しかし，前稿で述べたよ うに建設目的に, 建築美の表現や内部の展示で日本美術 の変遷を表すことがあり, 建築形態や表現する時代の選 択には，関係者の建築史観や歴史的美術に対する評価や 思想（以下「美術史思想」とする）が影響していた筈で ある。ところが, 先に挙げた人物のうち, 建築史観が知 られるものはおらず，久留は後で述べるように日本館の モデル選定に深く関与していなかったようである。また， 美術史思想についても, 九鬼と山高は日本館の計画段階 で調査を行った帝国博物館の総長と理事であり，重要な 役割を果たしていたと考えられるが, 彼らの美術史思想
を知る史料に乏しいことから ，それを把握することは 難しい。しかし, 岡倉は前稿で述べたように, 九鬼や山 高以上に鳳凰殿の形態形成に重要な役割を果たしていた と考えられる。さらに，岡倉が東京美術学校で行った授 業の筆記録『日本美術史】は，鳳凰殿の設計時期とほ ぼ一致するものであり，その中で各時代の美術を評価す るだけでなく，日本美術の特質にも触れるなど，当時の 彼の美術史思想がよく現れている。また，当時の岡倉と 九鬼は「同心一体」5)とまで形容されるほどであるから， 両者の美術史思想に大きな隔たりは無かったと考えら れ, 岡倉と山高の関係についても, 二人とも九鬼の許で 活動する間柄であったから，この両者の場合も美術史思 想的に相入れぬものであったとは思われないお。

これより, 鳳凰殿の形態形成における美術史思想的背 景の多くが, 岡倉の『日本美術史』より考察することが 可能と考えられる。

なお，本稿で使用した資料は，この『日本美術史」の 他, 日本政府のシカゴ博についての正式報告書『臨時博 覧会事務局報告』(臨時博覧会事務局, 明治 28 年)（以 下『報告書』と呼ぶ), 岡倉や久留が鳳凰殿について述 ベた文章,『官報」, 当時の新聞》なぼを用いた。

\section{II. 鳳凰殿の内容}

日本館は鳳凰堂をモデルとして建てられ，「鳳凰殿」 と名付けられた。岡倉は, 鳳凰殿の英語による解説書で 
ある『THE HŌ-Ō-DEN』8) (以下『英語解説書」とする) を執筆しており，その中で鳳凰堂について説明した後，

鳳凰殿について以下のように述べている。

“The Hס-ס-Den now exhibited is substantially a replica of the edifice at $\mathrm{Uji}$, somewhat smaller in size and modified to adapt it for secular use."

訳：いくらかの縮小と現実的な使用に対応するために修正さ れてはいるが，ここに展示した鳳凰殿は実質的に宇治にある その寺院の模造である。

しかし，現実には鳳凰殿は鳳凰堂の単なる模造ではな く, 平安中期, 室町, 江戸の三時代を表現した三棟の建 物からなっていた。

鳳凰堂ノ様式二則リ一聯三棟ノ家屋 ヨ建築シ而シテ其内部ノ 装飾八藤原足利徳川ノ三時代二符合スルモノヨ施シ（略）

[「報告書」第四章第二十款鳳凰殿］

ところで，全体のモデルとして鳳凰堂があったが，三 時代を表したそれぞれの建物にもモデルが存在した。

『報告書』では，左翼の平安中期を表現した棟は，基 本的には鳳凰堂の様式に基づき, 寝殿造を組み入れたも の, 右翼の室町時代を表現した棟は, 当時の書院と茶室 を再現したもの, 左右の建物の約 2 倍の面積を持つ ${ }^{9)}$ 中 央の江戸時代を表現した棟は，八代将軍の頃の大名屋敷 を再現したものとしている。

左方藤原時代/宮殿八当代ノ建築二係儿宇治八鳳凰堂二基キ テ大體ノ形式 取り之二参配スル二公卿貴人ノ建築 シモノニシテ (略)

右方足利時代ノ建物八当代ノ書院卜茶室 7 現セルモノニシテ

(略)

中央ナル徳川時代ノ建物八総テ当代諸侯ノ邸ヨ写シタルモ， ナリト雖乇其室内ノ装置八全ク八代将軍ノ時代二於ケル大名 ノ邸宅二擬シ（略）

[「報告書」第四章第二十款鳳凰殿]

『英語解説書』は設計を担当した東京美術学校の校長 である岡倉が著したものであるところから，モデルがよ

り具体的に述べられている。

平安中期の棟について,

“The left wing of the Hס-ס-Den here erected is constructed in accordance with the principal architectural features of the Fujiwara epoch, specially copied from the Phoenix Hall at Uji, and from the apartments of the Imperial Palace at Kyoto"

訳：ここに建てられた鳳凰殿の左翼は, 藤原時代の建築的特 徵に則りながら建設されており, 特に宇治鳳凰堂と京都御所 を真似ている。

また，室町時代の棟については

"As a characteristic representation of the art of this epoch, the interior reproduces, with but slight changes, a room in Gin-kaku-ji (SilverPavilion)"

訳：この時代の美術の特徴的な表現として, その内装は僅か な変更はあるが, 銀閣寺 (シルバー・パビリオン) の一室を 再現している。

江戸時代の棟は
"The hall is a replica of a room in the old castle of Yedo (Tokyo)."

訳 :その堂は江戸 (東京) の古城の一室の複製である。 と, 述べられていた。これより, それぞれの棟のモデル は，平安中期は鳳凰堂と京都御所，室町時代の内装は銀 閣寺, 江戸時代は単なる大名屋敷ではなく, 江戸城であっ たことがわかる。

しかし，前稿でも述べたように，設計にあたった久留 は，各棟の外観をそれぞれの時代の様式で正確に再現し たのでは全体としての建築表現を生み出すことはできな いと判断し，各時代の意匠に変更を加えている。

廊下八全ク藤原氏ノ時代ノ製デアリマスガ即千丸柱デ廊下二 高欄カツイテオリマス徳川幕府/建築ニハ高欄ハナイ併シナ ガラ藤原氏ハ高欄ガアル夫レデ余儀ナク徳川足利二モ高欄 附ケテ同様二見ヘル様ニシマシタ

[久留正道「米国博覧会へ出品八鳳凰殿二付テ」「工学会誌]

(M 26.10)]

本来, 室町や江戸時代の縁には高欄が無いのを知りなが らも三棟とも高欄付としたのは，平安中期の棟に合わせ た結果であるとしている。この他にも室町時代の棟の舞 良戸を平安中期の棟の部に合わせて格子状のものに変 え, 平安中期や室町時代の建物は通常檜皮直か蒠苜であ

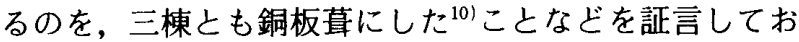
り，全体として「同様二見ヘル」ようにしたのである。

『英語解説書』の最後で, 岡倉は以下のように述べて いる。

"The building of the Hס- $\delta$-den are built of unpainted wood, and principles of Japanese construction and proportion are wholly adopted."

訳：鳳凰殿の建物は素木で建てられ，日本建築の構造と比例 の原理が全面的に採用されている。

三時代を表現しながらも，外観的にはまとまりのある形 態を示した鳳凰殿は，日本建築独自の美を表現するもの であると岡倉は考えていたようである。

\section{III. 日本館計画の推移}

日本館は，計画当初から鳳凰堂をモデルとしたもので はなく，様々な過程を経て形態は決定されており，この ことは鳳凰殿の形態を考察する上で重要である。

『報告書』によれば，日本館を建設するに際して鳳凰 堂と金閣寺のいずれかをモデルとすることになり，調査 の結果, 鳳凰堂に決定したとしている。

初入右ノ古代家屋ノ形状及七其内外/装飾八金閣寺卜鳳凰堂 トノ二様二就キ其一ヨ選択スルコト、ナシ調査ノ末鳳凰堂二 決シ（略）[報告書」第四章第二十款風凰殿］

『報告書』には，鳳凰殿の形態形成の過程を伝える記 述はこれだけであり，充分ではない。さらに重要な点は， モデルが最終的に決定する以前の段階では，金閣寺がよ り有力な候補であったような形跡が見られることであ る。これを当時の新聞などの資料から追ってみる。 


\section{III-1 日本館の計画の開始}

設計者久留が鳳凰殿の工事の為にシカゴへ出発する前 に工学会で行った「演説」” は，その形態が決定するま での経過をよく伝えている。それによれば, 日本館の計 画が開始されたのは，明治 24 年 9 月頃であった。

表作年/九月カラ其話が起ツテドウモ今時ノ家习出品シテハ 面白クナイカラ日本/古代ノ家习出品シヤウジアナイカサウ シテころんぶすが覀米利加き発見シタ頃/家が宜カラウカラ 其時分/家习出品シヤウジヤナイカト云フ説ガ起ツタ其頃, 建築八宜イコトニ八皆美術的/建築テアルカラ…サウ云フコ トガ分ツタラ寧口恃代二分ケタラ宜カラウト云フコトヨ帝国 博物館二於テ色々取調ベタシテ之き徳川, 足利, 藤原ノ三時 代/建築ニシヤウト云フコトニナリマシタ

[久留前揭「米国博覧会へ出品/鳳凰殿二付イテ]]

これより，まず歴史的様式に基づいた日本館を出品す ることとなり，次いで，その様式をコロンブスがアメリ 力大陸を発見した時代のものとしようとしたことがわか る。コロンブスのアメリカ大陸発見が 1492 年であるか ら,これは室町時代と考えられる。しかし，その時代の 建築は「美術的」なものであるから，それならば時代分 けをして建物を出品したほうがよいということになっ た。そこで帝国博物館が表現する時代の調査を行い，選 ばれたのが江戸，室町，平安中期の三時代であった。

時代が決まった後，それをどのように表現するかが問 題となるが，当初は一棟の建物で三時代を平面的に分け て表す案が考えられた (図一1) $)^{12}$ 。「演説」の内容から， この案は久留が作成したのではないことがわかるが，そ れでも詳しく説明しており ${ }^{13)}$, 計画がある程度進んだも のであったことがわかる。しかし，この案は久留が述べ るところの「刺身ノ脇二以ツテ徃ツテ既テモ附ケルヤウ ナ」ものであり，これでは建築美を表現することは叶わ ず，前稿でも述べたように九鬼の判断で実在の古建築を モデルにして日本館を設計することになった。その結果 選ばれた古建築が金閣寺と鳳凰堂で，この選定は明治

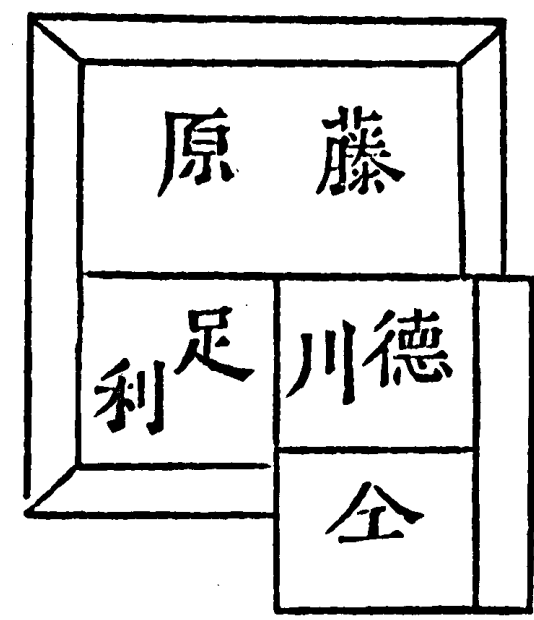

图一1 計画当初の日本館平面図 [久留正道「米国博覧会へ出品 人鳳凰殿二付テ」[工学会誌」(M 26.10) より]
24 年 12 月初めまでになされている14)。

III-2 敷地獲得から設計終了まで

同年 12 月 28 日には，米国博覧会事務局との種々の交 渉の為に, 事務官手島精一がシカゴへ出発する。この時 の交渉に日本館の敷地請求が含まれていた。日本が請求 した敷地はジャクソン・パーク内のウーデッド・アイラ ンドで,前稿で述べたように敷地獲得交渉は難航したが, その理由の一つとして建物自体の問題があった。日本の 事務局は日本館を博覧会終了後シカゴ市へ寄贈する計画 であったので，そのことがまず問題となり，次いで建物 の高さが問題となった。会期終了後, その敷地はシカゴ 市管轄の公園となるため，手島の交渉相手は米国側事務 局だけでなくシカゴ市公園委員会にまで及び，建物の形 状などを説明した結果，低い建物であることを条件に日 本館の敷地とする許可が与えられた ${ }^{15 !}$ 。日本館の敷地が 確定したことを伝える新聞記事は，日本では翌 25 年 2 月 25 日の紙上に載せられており，交渉はこの時迄に終 了していたことがわかる。

これと前後するが，日本館の計画が企画段階から設計 段階に移るのは，東京美術学校に設計が依頼されてから と考えられる。同校の明治 25 年度の年報には，鳳凰殿 の設計に関連した記述として，以下のものがある。

(一月) 二十二日文部省ヨリ閣龍世界博覧会へ本校ヨリ出品 費用トシテ農商務省ヨり配付ノ金二千七百円交付七ラレ乃絵 画科㓮刻科美術工芸科中彫金鋳金蒔絵等/諸科へ右金額分配 各科出品ノ準備二著手セり（略）

三月八日兼テ達セラレタル閣龍世界博覧会へ臨時博覧会事務 局ヨり本邦家屋出陳二付其構造并二室内装飾等/設計二付取

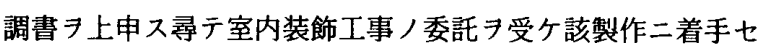
リ（括坬内は筆者による）[東京美術学校第四年報 [處務 $\left.]^{161}\right]$

また，同年 2 月 26 日の『読売新聞』の記事「宇治の 鳳凰堂」では, 他紙より一日遅れて日本館の敷地確定を 報じているが, 同時に東京美術学校で日本館の設計中で あることも記している。

これらから, 東京美術学校内に於いて 1 月 22 日に少 なくとも日本館で展示する美術品等の準備だけは開始さ れており，2月25日迄には建物自体の設計も依頼され， 敷地獲得にともない計画は企画段階を脱し，3月 8 日に は取調書を上申していることから，実施設計の態勢に 入ったと思われる。

次いで 4 月 23 日, 久留正道は「家屋建築工事監督」 を事務局より嘱託されている17)。

5 月 17 日の各新聞は, 日本館の施工が日本土木会社 に決まったことを報じているが，注目すべき点は，この 時点で同社が既に深川の工場で工事に入っているとして いることである。ところが，5 月 23 日に米国の博覧会 建築部長ダイヨン・ゼラルヂンより,日本館の建設規模, 配置, 人夫や材料の到着や着工時期についての問い合わ せがあったにもかかわらず，事務局はすぐに回答してい 

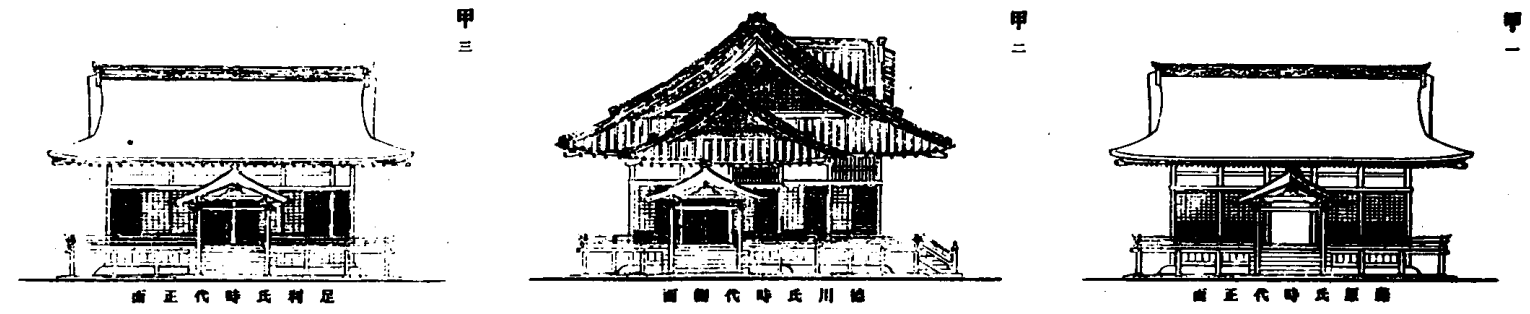

$\boldsymbol{z}$

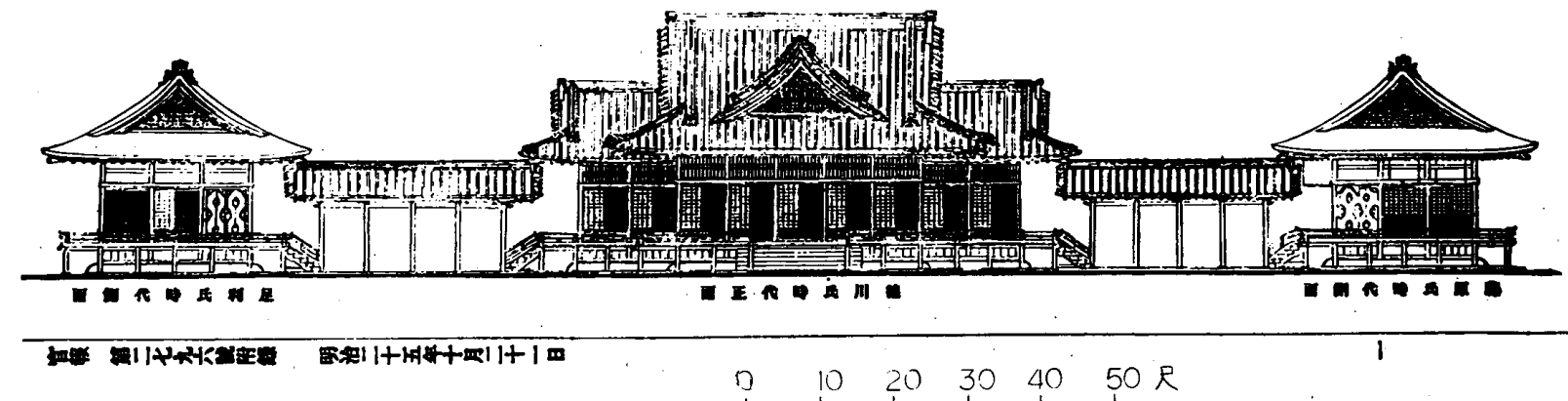

図一2 凮凰殿・立面図 [「コロンブス世界博覧会出陳日本建物 縮困」「官報」（M 25.10.21 附録）］

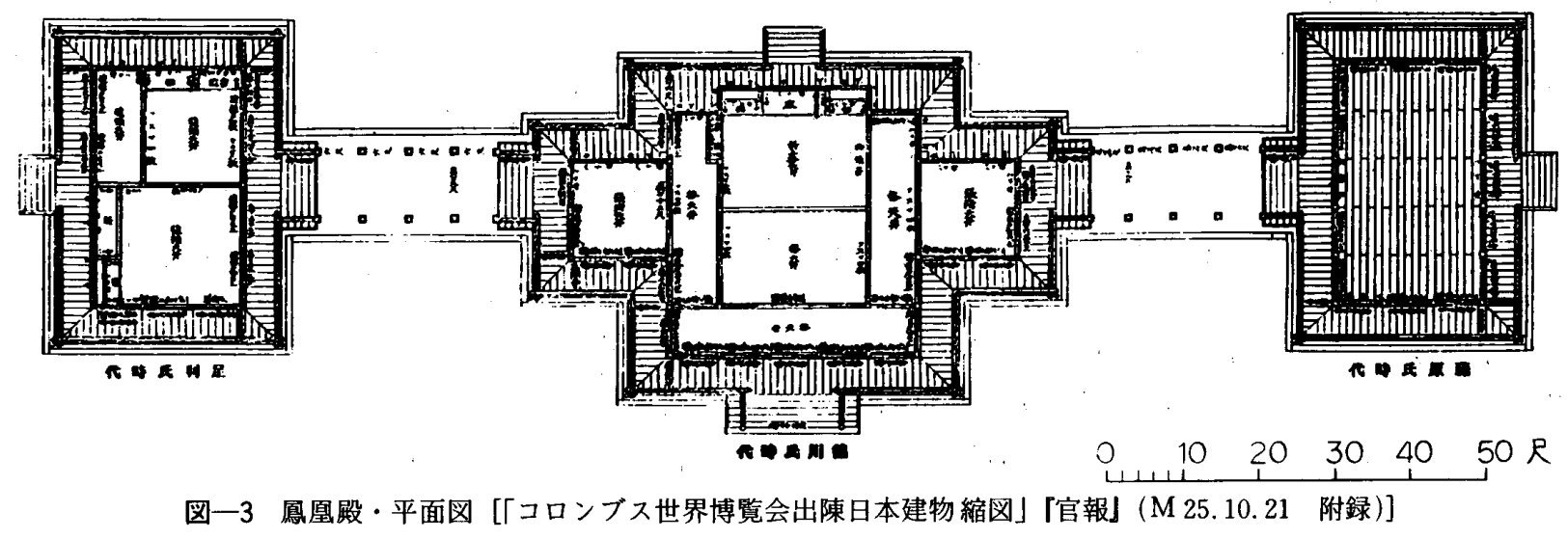

ない。ようやく6月 23 日に手島精一が一応の回答をし， 次いで 7.月 2 日に建築部長 D.H. バーナムに設計図及 び説明書を送付し,同時に竣工予定も伝えたのであった。 これを受けて，7月 23 日にはバーナムより米国側の博 覧会総裁ジョージ・アール・デヴィスの承認を得たと通 知があり,さらに 8 月 10 日には日本の事務局総裁に対 して, 米国側から正式に承認が通告され，これで日本館 の設計についての交渉が終了した ${ }^{18\}}$ 。

5 月 17 日に工事に入っていたことと, 同月 23 日の米 国側の問い合わせに対して即座に回答していないという 事実から，この時点で設計が完了していたとは断言でき ないまでも, 基本的な部分の設計は終わっていたと見て よいであろう。さらに，遅くとも 6 月 23 日もしくは 7 月 2 日迄には設計図は完成していた。

\section{III-3 日本館のモデルの決定}

前述のように，明治 24 年末の段階では日本館のモデ ルとして金閣寺と鳳凰堂が挙げられていた。しかし, 翌 25 年になると新聞記事の殆よ゙が日本館は金閣寺を模し たものであるとして, それに関する各種の内容を報道し
ており，このことは 6 月 30 日にそれが鳳凰堂の模造と

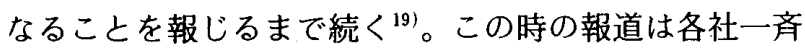
のものであることから；6月末に日本館の設計がほぼ完 了したことで, 事務局はその内容について記者発表を 行ったと考えられる。この時の報道で注目されるのは, 単に日本館のモデルが鳳凰殿となったということだけで なく, 金閣寺から変更された理由までも記していること である。

閣龍世界大博覧会へ我政府より歴史的美術品として金閣寺の 構造を出品する計画なりしも米国政府より高閣の建築を拒 るつ事となり中途より佘良鳳凰堂に変更し(略)

[「世界博覧会出品鳳凰堂の構造」「読売新聞」(M 25.6.30)] これによると, 変更理由は米国側から高層の建築物を拒 否されたことによるとしている。また,このモデルの変 更をいち早く報じた『東京日日新聞』には，興味深い理 由が載せられている。

㧋この古代建築の出品にて最初金閣寺と極しもの俄に平等院 の鳳凰堂の模造へと変へたるを如何にといふっに我が事務官の 某, 彼国へ航つて日本帝国の出品京都の金閣寺と名のりを挙 げたるに彼国の委員大いに驚きて左様の大物の御出品此方会 
に取り有り難くはあれど少しく迷惑といふべき方にて左程広 大なる大伽藍を俄かに建てられては周囲の景色の取り合わせ にも差響き各国の出品者の苦情等もあるべき䯘といふろに, 事 務官さらばアレに見ゆるウーテッド島彼の全面を我国に貸し 與へらるべし左あらば此方にても四隣の苦情これ無きやうに 恰好の物を出品せんと約束したるが此れにより俄に金閣寺に ては広大に過ぎたり宜しく鳳凰堂たるべしとの評議になれる なりとかや.(略) $[\mathrm{XYZ}$ 生「米国博覧会に就ての一二（鳳凰 堂の事)「東京日日新聞」(M 25.6.25)]

記事はこのあと，米国側の委員が勘違いして金閣寺を実 際よりもはるかに大きなものと思い込んだとのことが述 ベられている20)。その内容については疑うべき点もある が, 日本館のモデルの変更と言えるようなものがあった ことは,その理由までも載せられていることからほぼ間 違いない。

さらに，敷地確定に際してシカゴ市公園委員会が日本 館が低い建物であることを条件とした理由は，『東京日 日新聞』が報じるように，交渉時に手島が金閣寺をモデ ルとした日本館を説明したと考えれば理解がしやすい。 もし, 最初から鳳凰堂をモデルとした日本館を説明して いたとすれば，このような条件は付けられなかったので はないだろうか。

これらの状況より，日本館のモデルは当初金閣寺が有 力であった可能性が高い。それゆえ, 事務局から正式の 発表はないものの, このことが新聞各社に伝わり報道さ れていたのであろう。鳳凰堂が日本館のモデルに決定す るのは, 敷地獲得後, 東京美術学校が取調書を上申する

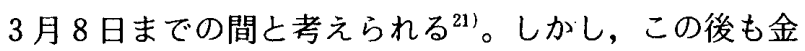
閣寺のままで報道されていたのは, 日本館の内容が確定 する 6 月末までは事務局よりモデルについての発表が無 く, 敷地や施工会社などの情報だけが発表されるだけで あったため，それらを報じるためにかつて入手していた 情報をもとに日本館のモデル名を記事に付け足していた と考えてよいであろう。

\section{N. 三時代の表現と岡倉の日本美術史思想}

先に見たように，当初の時点では日本館を室町時代の 建築様式で建てようとしていたが，それが美術的に優れ たものであったことから, 計画は変更され拡大していっ た。しかし，その建築が美術的であることが，複数の時 代表現に直接つながるものではない。これより，変更理 由及び表現することになった時代の選択理由を，岡倉の 日本美術史思想を踏まえて探ってみたい。

IV -1 岡倉の日本美術史観

岡倉の「日本美術史」は，絵画や彫刻を主なる対象と したものであるが，その中で文学や建築について触れら れることもあり, 芸術一般の時代特性について述べたも のと捉えることも可能であろう。

岡倉は日本美術の歴史を大きく「上古」「中古」「近世」
表 岡倉の【日本美術史」における歴史区分

$$
\begin{aligned}
& \text { 上古 }\left\{\begin{array}{l}
\text { 推古帝時期 } \\
\text { 天智時期 } \\
\text { 天 平時期 }\left\{\begin{array}{l}
\text { 第一䀦 } \\
\text { 第二期 }
\end{array}\right.
\end{array}\right.
\end{aligned}
$$

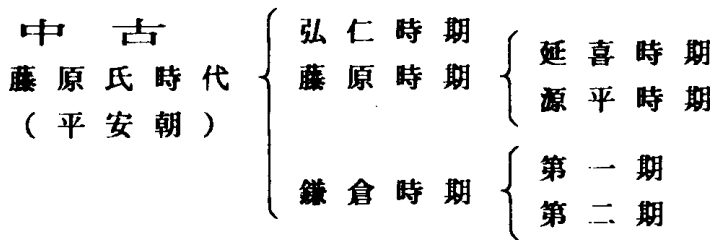

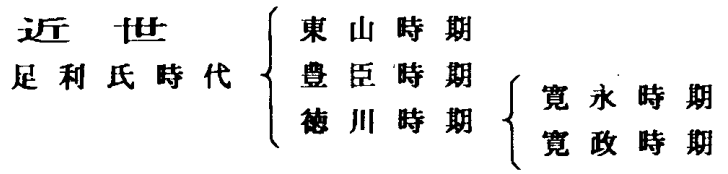

の三つに分け，それぞれをまた三つの時期に分割し，場 合によってはさらに二分割している22) (表参照)。

また，日本美術の特幑の一つに「変化に富むこと」を 挙げ，三時代の精神と表現を，「上古」は「理想的」で「壮 麗」,「中古」は「感情的」で「優美」,「近世」は「自覚 的」で「高淡」としている。

精神上より云へば，奈良朝の理想的なる，平安朝の感情的な る，足利の自覚的なる，之れを其の形に現はれたるところよ り論ずれば，壮麗，優美，高淡の三大変化を有す。

[「日本美術史」「総叙」(以下は同書の章名だけを示す)]

これらの時代区分の内で，美術が最高に発達していた のは「天平」「延喜」「鎌倉」「東山」の四期としていた。 此の中に於て, 最高点に達せしは天平, 延喜, 鎌倉, 東山な るべし。[同上］

そして,それぞれについては以下のように述べている。 「天平」については, .天平時期に至りては奈良美術は極点に達せり（略）[同上] として，「上古」の最高点にあったとしている。

「延喜」については, 支那に則ることなく，旧来の文化を消化して日本的となりた り（略）

純然たる日本風を帯びたること（略）

延喜美術は優美なり（略）[「平安時代」]

として，延喜以前の文化を消化した結果，純粋な日本性 を得て，「中古」の特質である「優美」を持ったとして いる。

「鎌倉」については,「平安時代すなわち藤原時代美術」 には「剛健優美の二性質ありて相並びしこと」として， 藤原氏の盛時には優美に傾いていたが，保元平治の乱以 降，剛健の機運を生じ発達した結果，

鎌倉時代に至れば，率直剛健の一時代をなしたり。然れだも 此の一時代は藤原時代残余の美術此に発達せりと見て可な り。(傍点筆者) [[鎌倉時代]] 
としている。すなわち，「藤原の盛時」とは異なる特質 である「風健」を持っているとしている。

「東山」については, 足利時代最盛の期なり。[「足利時代」] として,「近世」の最高点としている。

これより，この四期のうちで「天平」「東山」はそれ ぞれ「上古」「近世」の二時代を代表するものと考えて よい。

「延喜」「鎌倉」については，いずれも「中古」に属す るものであるが，この時代の特質は「延喜」に現れてお り，「鎌倉」は「藤原時代残余の美術」が発達したもの と見てよいと述べていることから，「中古」時代を代表 するものは「延喜」としてよいであろう。

一方, 鳳凰殿との関連で『日本美術史」を見る場合, 「日本性」と言う点が重要であるが，これは「上古」の「天 平」には既に存在したとしている。

推古時代に於て入りたる新風は, 此の時代に至りては, 化し て日本風となりて進歩せり。[「天平時代」]

しかし、これについては以下のようにも述べている。

天平, 固より純然たる日本風なれども, 其の之を表す方法は 延喜を以て一層日本的なりとす。[「平安時代]]

これより, 岡倉は日本性については「天平」「延喜」が 同質でありながらも，「延喜」のほうがより日本的であ ると考えていたと思われる。

さらに, 日本性は各時代に存在しているとしながらも，

最も醇乎たる日本風は延喜時代に胚胎したるものにして(略) [「平安時代]]

と述べ「優美」ということについては，

日本的のものと謂へば，この種のもの（※）を指さら゙る可か

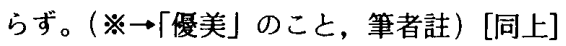

とするなど，岡倉は日本美術の全歴史を通じて「延喜」

を最も日本的と考えていたと思われる。

これより，岡倉が日本性の点で「天平」「延喜」のい ずれかを選ぶとするなら，後者であったと推測できる。

「東山」時期を含む「近世」の日本性については, 以 下のように述べている。

奈良朝の壮麗，藤原時代の優美，以て外国に比すべきものあ り。(略) 独り我が足利氏時代（略）比すべきものあらず。 [「足利時代]]

これは「近世」が持つ「高淡」の表現を指しているので あるが，外国には存在しない日本独自のものであるとし ている。また，

西洋人が現今の日本美術を以て淡白なりと評するは，此の高 淡に原くものにして，邦人と雖ども中世以前に在りては壮麗 優美の性質に富みたりしが, 四百年前, 足利氏時代の為めに 感化せられて高淡となれり。[同上]

としており，外国人から胃た現在の日本美術の表現は， 「近世」のものに由来し，「近世」になって初めて「高淡」 の性質を得たとしている。岡倉はこの原因を鎌倉時代の
禅宗の輸入にあるとしていた。

これより，岡倉は「近世」の日本性はそれ以前に見ら れない独自のもので，外国人にとって「日本」を最も感 じさせるものであると考えていたことになる。

よって，岡倉は「東山」の美術を形態的に優れている だけでなく，それ以前に見られない日本性を持つとして おり，外国における日本性を示す場合には恰好の時期と 考えていたと言えよう。

$\mathrm{N}-2$ 三時代の表現

日本館で複数の時代を表現することへの変更は，日本 美術の変遷を表現しようという意図のもとに行われたと 考えられる。先に述べたように，岡倉は「日本美術史】 の中で, 日本美術の特徴の一つに「変化に富むこと」を 挙げ，各時代の精神と表現を述べた後に，

同一種族にして此の三者 ${ }^{23)}$ 具備するは世界其の例を見ざる

処，以て大和民族が美術思想に富めるを証すべし。 と述べ,さらに，

独り我が人種に限りて此の三大変化 24$)$ を有するは, 甚だ能力 の特絶なるを証すべく，以て万国に誇るに足れり。

とするなどここれ世界に誇れる日本人の特質としてい $る^{25)}$ 。これより，岡倉がシカゴ博という機会を捉えて， この世界に誇れる日本美術の特質を表明しようとしたと しても不思議ではない。そのためには, 少なくとも三時 代を表現する必要があった。日本館で三時代を表現する ことを提案した人物が誰であるかを知る史料は現在まで 発見されていないが，岡倉は前稿で述べたように美術出 品の分類変更の提案をするなど，積極的に日本美術の地 位向上に努めていた。これより, 日本館が室町時代の様 式で建てられることになった時, それが美術的であるこ とに注目して，岡倉が複数の時代を表現することを提案 した可能性は高い。その場合, 岡倉が表現しなければな らないと考えたのは, 少なくとも三時代, それも奈良・ 平安中期・室町の各時代であったはずである。

$\mathrm{IV}-3$ 三時代の選択

ところが，実際に表現された時代は，岡會が望んだ三 時代そのものではなかった。計画を変更し複数の時代を 表現しようとしたことは, 全く美術的な動機であったが, 現実には政治的要因が時代選択に入り込む事になったの である。各時代が選ばれた理由は『報告書」には述べら れていないが, 久留の「演説」から知ることが出来る。

先の引用文にあったように, 当初の段階で室町時代の 建築様式で日本館を建設しようとしたのは，コロンブス のアメリカ大陸発見四百周年を記念するというシカゴ博 の開催目的に起因するものであった。すなわち、コロン ブスがアメリカ大陸を発見した当時のものを出品しよう というもので, 室町時代の美術史的評価とは無関係な動 機であった。この後, 室町時代の建築が美術的なもので あることにより計画は変化してゆくが，このような政治 
的要田が室町時代を選ばせた理由の一つであった。

江戸時代についても，シカゴ博がアメリカで開催され るものであることから, 日米の友好を記念して選ばれて いる。すなわち, 日本とアメリカが初めて条約を結んだ 時代を表現しようというものであった。

此足利氏八凡ソ五百年頃 ${ }^{26}$ 藤原氏八八百年前徳川氏八始メテ 要米利加卜條約 7 結ンダノガ嘉永安政ノ頃ノ風ガヨカロウ其 時代ノモノヨ取ツテ計画シタラメッポウ宜カラウト云フノデ 其頃二極りマシタ

[久留前揭「米国博覧会へ出品/鳳凰殿二付イテ」]

ところが，『報告書」では江戸時代を表現した棟のモデ ルの時期は「八代将軍ノ頃」としており, 久留の述べた 時期之異なる。よって,「嘉永安政ノ頃」の建物を出品 しようとしたことは, 江戸時代を表現する契機となった のであって, 現実には美術史的評価から八代将軍の時期 を表現することになったと考えられる ${ }^{27)} 。$

このように，室町や江戸時代の選択には政治的要因が 働いていたが，平安中期についてはアメリカとの関係が 考えられず，三時代を表現することになった本来の美術 的な目的から選ばれたと考えられる。

そこで問題となるのは，平安中期に対する美術史的評 価である。岡倉が高く評価していた三時代のうち，室町 時代は既に政治的理由からも選ばれていた。残る二時代 のうち，岡倉は「天平」よりも「延喜」を日本性の点で 高く評価していた。よって, 岡倉の美術史評価からは平 安中期が選ばれるのは当然であうた。

以上のように，表現された三時代が選ばれたのは，日 本美術の変遷の表現という目的からだけではなかった。 室町時代が美術史的評価だけで選ばれたのではないよう に，政治的理由で江戸時代が選ばれ，美術史的評価だけ で選ばれたのは平安中期だけであった。

しかし，室町時代は，政治的理由が選ばれた契機であ るにしても, 日本美術の変遷を表すという美術的展示を 導いた以上,美術史的評価からも選ばれたと考えてよい。 江戸時代についても，政治的要因よりも美術史的評価を 重視して表現する時期を変更している。このように，政 治的理由から選ばれた時代は，日本美術の変遷の表現と いう，前橋で述べた鳳凰殿建設の目的を大きく阻害する ものではなかった。

\section{V. 日本館のモデルの選定}

日本館のモデル候補に選ばれた古建築は鳳凰堂と金閣 寺であった。モデル無しに三時代を表現しようとしたが, 建築美を生み出すことが出来ず，九鬼の判断で古建築を モデルとすることになったのであるから，この点を重視 してモデル選定が行われたはずである。これより，この 二建物が選ばれた理由として，三時代を表現するのに適 した構成を持っていたことが挙げられる。金閣寺は三層, 鳳凰堂も三棟であり，構成的としてはいずれも三時代を
表現するのに都合が良いものであるから，モデル候補に 選ばれたと考えてよいだろう。

しかし，これらは日本の古建築の中から漠然と選ばれ たのではなかった。『報告書』では, 日本建築がその美 を発揮していたのは奈良時代に始まり, 平安中期・室町 時代に頂点を極めたとしている。

我国古来建築ノ精美ヨ盡シ雅巧ヨ致シタルハ天平二始マリ藤 原足利ノ二氏二至りテ極レリ

[報告書」第四章第二十款鳳凰殿]

これら三時代が高く評価されているのは，岡倉の『日本 美術史」と同じであり注目されるが，天平は「始マリ」 で，平安中期・室町時代に「極レリ」としている以上, 後の二時代をより高く評価していたと考えられる。これ より，鳳凰堂と金閣寺は平安中期と室町時代の建物であ ることから選ばれたと考えられる。これを裹付けるもの に先の久留「演説」がある。日本館のモデル候補に金閣 寺と鳳凰堂が挙がったことから，久留はそれらを実地に 見に行ったことを述べているが，その時に京都や大津近 辺を訪れ，この二建物以外にもモデルとなる建築物を探 したようで,そのことについて以下のように述べている。 外二モ西京, 大津辺习見マシタケレドモ其時代三建方方良市 家屋八是レヨリ外ニハナイ (傍点筆者)

「其時代」とは，鳳凰堂と金閣寺が建てられた平安中期 と室町時代と考えられるから，モデル候補となる「良仡 家屋」をこの二時代から選ぼうとしていたことがわかる。 すなわち，モデルの選択は，先に時代が決められていて， その時代の中で探した結果であった。

この二候補から，最終的に鳳凰堂が日本館のモデルに 決まったのであるが，その理由として日本館の計画に当 たっていた人々が平安中期を重視していたと思われる点 は見逃せない。このことは図一1の平面で「藤原」時代 のものが最も大きな面積を占めていたことに示されてお り，岡倉は『日本美術史』の中で「延喜」を最も日本的 な時期としていた。よって，これが鳳凰堂をモデルに選 んだ理由の一つになったと思われる。

また，久留は「演説」の中で敷地周囲との適合性を評 価して，アメリカという山のない場所に建てるには鳳凰 堂の方が相応しいとしている ${ }^{28)}$ 。

金閣卜云フノ八山二倚り水二沿フテアノ家八出来テ居ル (中 略）丸ルデ山水デ位置ヨ為シテ居ル是レア亜米利加二持テ徃 クト水ハアルケド山ハナイ、から斯ウ云フ建物ヨリ平場ノ 建物ノ方ガ宜イ鳳凰堂 7 見ルト成程鳳凰堂八良イト云フコト ガ分ツタ即千平場ノ建物デアツテ宇治ノ川二臨ンデ其家八美 術的二能ク出来テ居ル（以下略）

この他にも理由は考えられるが29)，その最も現実的な ものは，先に述べた敷地獲得の際に米国側から付けられ た条件である。その条件とは低い建物であることで，乇 デル選択に於いて避けることのできない要因となったは ずである。これより，金閣寺よりも低い建物である鳳凰 
堂がモデルに選ばれやすい状況にあったといえよう。

\section{VI. をとめ}

シカゴ博以前の日本館と比較した時, 鳳凰殿建設の建 築史的な意義は，それが本格的日本建築であったことだ けでなく，古建築をモデルとして日本建築の歴史的様式 を表現したことにあるだろう。

前稿で述べたように，九鬼や岡倉の国粋主義が鳳凰殿 を本格的な日本建築にしていた。しかし，それだけでは 古建築をモデルとし歴史的建築様式を表現することには ならない。すなわち，単に日本的なものを表見するだけ であるならば，当時の本格的和風建築を建てればよかっ たはずである。しかし，それでは「面白クナイ」と判断 したことにより歴史的建築様式を表現することになっ た。久留「演説」では，この時点で計画を進めていた人 物の名は出てこないが, その後の進展からは, 九鬼や岡 倉らがこの判断を行ったものと考えられる。事実, 実在 の古建築をモデルとすることを提案したのは九鬼であっ た。また，岡倉は当時自らが校長であった東京美術学校 で，日本美術の伝統を踏まえた上で，新しい日本美術を 創造することを生徒たちに求めているなど，彼が歴史を 重視していたことは先学による多くの論考で確かめられ ている。このように，九鬼や岡倉らを始めとする日本館 の計画を進めていた人物が歴史を重視していたという, いわば歴史主義ともいうべきものが，歴史的建築様式を 表現するという判断を導き，その結果，鳳凰殿の建築史 的意義を高めることになったといってよいであろう。

歴史的様式を室町時代のものにしようとしたことは, 日本美術の変遷を表現することを導いた。複数の時代表 現を提案した人物を知る史料はないが，之の美術史思想 から岡倉であった可能性は高い。この時, 岡倉は世界に 誇ることの出来る日本美術の特徵である「三大変化」を 示すために, 表現する時代として奈良・平安中期・室町 の三時代を考えていたはずである。

ところが，実際に表現された時代の選択には，万国博 の開催目的や日米の外交といった政治的要因が影響して いた。この点は, 鳳凰殿が万国博で建設される日本館で ある以上，宿命的と言えるであろう。しかし，岡倉が望 んだ平安中期と室町時代は選ばれ，江戸時代についても 政治的理由から表現されるはずであった時期から，より 美術的であった時期に変更されており，岡倉の構想が大 きく阻害されることにはならなかったと思われる。

鳳凰堂と金閣寺が日本館のモデル候補に選ばれた点 は, 三時代の表現という計画的な理由に基づくものであ るが, より重要な点は, モデルが日本建築の全時代から 選ばれたのではなく, 平安中期と室町時代という特定の 時代から選ばれていたということである。鳳凰殿の建設 に関係した人々の意識として, 個々の古建築より時代表
現の方を優先していたことは注目に值する。

そして最終的に鳳凰堂がモデルに選ばれたが, その理 由としては敷地交渉の段階で米国側から高層の建物を拒 否されたことが大きい。この段階で米国側に金閣寺をモ デルとした日本館を提示したことを示す確実な史料は存 在しないが，交渉に当たった手島精一の伝記や当時の新 聞などの資料からは，当初，金閣寺が鳳凰堂よりも有力 なモデルであったことが伺える。金閣寺は日本建築の中 で特筆するほど高い建物ではないが, 三層構成であり, 鳳凰堂と比べれば絶対的な高さは大きい。これより，鳳 凰堂が高さの点でモデルとして選びやすいものであった と言える。また，岡倉を初めとする鳳凰殿建設の関係者 が平安中期を高く評価していたことも重要である。

このように, 政治的思惑や計画的制約が加わった結果, 鳳凰殿は，岡倉を始めとする日本館計画に当たった人々 が考えた日本建築や日本美術の粋を，理想的な形で表見 したものとまでは言えない。しかし，そこには岡倉らの 美術史思想が反映しており，「万国博の日本館」という 制約の中で, 彼らの考える日本的な美を表現するもので あったと言えよう。

\section{註}

1）当時の資料では「藤原時代」「足利時代」「徳川時代」之 表記している。

2）拙稿「1893 年シカゴ万国博における鳳凰殿の建設経緯に ついて」旧本建築学会計画系論文報告集」(1991.11)

3）九鬼隆一の日本美術史観については, シカゴ博当時のも のではないが、明治 41 年に大阪ホテルで行われた美術講 演の記録「九鬼男爵日本美術論」(非売品, 明治 41 年) で知ることができたが，岡倉の『日本美術史】と対立す るような点は感じられなかった。

4）岡倉の「日本美術史」講義は，明治 23 年より 3 年間開講 されており, 本稿で使用した阳本美術史」は，「岡倉天 心全集」第四巻（平凡社, 1980 年）所収のものである。 これは, 明治 24 年度の講義を記録した原安民筆記ノート を基にして，見存する他の資料などを用い，吉沢忠氏が 吉田千鶴子氏の協力を得て校正編集したものである。

5）伊藤正雄「福沢諭吉之岡倉天心一九鬼隆一をめぐる両者の 立場についで-」福沢諭吉論考」(吉川弘文堂, 昭和 44 年) より

6) 石井柏亨阳本絵画三代志」(ペりかん社, 昭和 58 年, 原出版昭和 17 年）から，岡倉に強い影響を与えたフェ， ロサと山高の間に絵画の制作の上で多少の軒軪があった ことが知られるが, それがシカゴ博当時の岡倉と山高の 関係に影響があったとは思われない。

7）資料とした新聞は「読売新聞】「東京日日新聞」「郵便報 知新聞】「大阪朝日新聞」「阪毎日新聞】である。ただし， 大阪系の新聞は当時の通信事情からと思われるが, 記事 が東京のものに較べ二三日遅れていることが多く, 日付 については東京系のものを重視した。

8) Okakura Kakuzo, Director of the Tokyo Fine Art School : THE HŌ-Ō.DEN (Phoenix Hall) An Illustrated Description of the Buildings Erected by the Japanese 
Government at the World's Columbian Exposition, Jack son Park, Chicago, K. Ogawa, 1893

9）「報告書」第四章第二十款鳳凰殿には，「其面積八中央約 ソ二十坪左右各々十坪許リナリ」とある。

10）屋根苟材を銅板とした理由は，三棟で統一した表現とす ること以外に, 鳳凰殿がシカゴ市に寄贈されるものであ ることから，耐久性のある材料を求めた結果であったこ とも，久留の発言の中にある。

11）この講演が行われた日時は,これが掲載された「工学会誌」 (M 26.10) には記載されていないが，その内容から見て 明治 25 年 7 月 15 日に工学会通常会で行われた久留の演 説「シカゴ博覧会二テ建築ノ日本家屋」と考えられ，同 誌に揭載される時点で改題されたと思われる。

12）「徳川」時代の部分が二つに分割されていたのは,「男子」 と「女子」の空間を表現するためであった。

13）この案を見て, 久留は「此位ノモノデ宜カラウト云フノ デ極ツタサウデシタカ元ヨリ白人ノ考デ戸ヨ揚ゲテアル 其御隣り八丸柱デ丸木ノ橡側 7 付ケル其徳川ノ大名風， 建築其又隣り八神社ノ額堂見ル様テマルデ刺身ノ脇二以 テ徃ツテ餡テモ附ケルヤウナ工合デ誠二面白クナイ」と 述べている。これより, 久留がこの案の作成に参加して いなかったことがわかり，またこのような詳しい説明を することができたことから，これがかなり具体的な段階 にまで進んでいたことがわかる。

14）明治 24 年 12 月 3 日の衆議院予算委員会で「政府委員」 がシカゴ博で建設予定の日本館の計画内容を説明してお り, 同委員会主査の小間肅が, 翌日の衆議院通常会で, そのことを報告している。小間のこの報告から，この時 には日本館が「藤原」「足利」「徳川」の三時代を表現し， 金閣寺か鳳凰堂のいずれかを模したものとなる計画で あったことがわかる。

15）手島工業教育資金団「手島精一先生伝」(非売品, 昭和 4 年)より

16）【東京芸術大学百年史」東京美術学校篇第一巻（ぎょうせ い, 昭和 62 年) 第三章草創期 所収

17)【故正員工学士久留正道君略官歴」「建築雑誌」(T 3.5) より。なおこのことを伝える記事は当時の「官報】に は揭載されていない。

18）以上は, 何れも「報告書」第四章第二十款鳳凰殿の記述 による。

19）先に挙げた「読売新聞」明治 25 年 2 月 26 日の「宇治の 凮凰殿」は日本館のモデルを鳳凰堂としているが, 同紙 もこの日以後の日本館を扱った記事では他紙同様に金閣 寺をモデルとしている。

また，日本館のモデルが金閣寺から鳳凰堂に変更され たことは，後で述べるように「東京日日新聞」だけが他 紙よりも早く，同年 6 月 25 日の記事で報じている。

20）米国側の委員は金閣寺を「聖ゼームス 寺」ほゼの広さ があり, 高さがエッフェル塔ほどもあると誤解したとし ているが, 真偽のほぼは疑わしい。

21）ただこのモデルの決定が米国側との交渉終結により直 ちに行われたものであるかは定かでない。米国側の条件 は高い建物でないということであり，また，後で述べる ように久留は全く別の条件から鳳凰堂をモデルとしたと 述べていることから，金閣寺をモデルとして低い建物を 計画したが，それではうまくゆかず，それにより，鳳凰
堂に変更したことも考えられる。

なお，久留は「演説」のなかで日本館のモデル選定に あたって自らも出張して金閣寺や鳳凰堂を見たことを述 べている。しかし, 当時の「官報」「官吏発著」によれば, 明治 24 年 10 月から翌 25 年 9 月までの間に久留が京都に 出張したのは, 25 年 3 月末から 5 月中旬にかけて第三高 等中学校に関係したものだけである。この時にそれらを 見たのであれば，モデル決定後の事後確認であったこと になるが，後で述べるように，久留はこの時にモデル候 補となる他の建築物も探していることから，この出張は 先の日時以前と思われる。久留は明治 25 年 2 月 6 日まで 文部省から「非職」を命じられており，この時に京都へ 赴いた可能性は高い。

22）この時代区分は, 「日本美術史」の最後の章である「総叙」 において行われたもので,「推古以前」の章で行われた時 代区分よりも詳しく分けられており, 各時代の名称も異 なるものがある。岡倉は日本美術史を体系的に編んだ最 初の人物として知られているが,このような点にも開拓 者ならではの不安定さが見られる。

23）「此の三者」とは,「上古」の「理想的」,「中古」の「感 情的」,「近世」の「自覚的」という精神のことを指して いる。

24）「此の三代変化」とは, 「上古」の「壮麗」,「中古」の「優 美」,「近世」の「高淡」という表現上の変化のことを指 している。

25）いずれも，「日本美術史」「総叙」より

26）室町時代の建物のモデルとなったのは, 前述のように銀 閣寺であった。しかし，これは 15 世紀末のものであり， 「五百年頃」前という久留の知識は誤っていたことになる。 ただ,これが金閣寺を指しているならば, 食い違いは生 じない。先に述べたように, 金閣寺から鳳凰堂へのモデ ル変更があり,久留の認識に混乱が生じていた可能性は ある。

27）岡倉や彼に影響を与えたフェノロサは, 明治初期の日本 美術を高く評価しておらず，このことが彼らに日本美術 の近代化を推進させたことは多くの先学により確かめら れており, 嘉永や安政といった幕末の日本美術について も同様の評価であったと考えられる。ただ，「八代将軍， 頃」とは享保年間を指すと考えられるが，この時期の日 本美術を岡倉がどのように評価していたのかは「日本美 術史」やその他の資料からは正確に知ることは出来ない。 「日本美術史」の時代区分では, 敦保年間は「徳川時期」 の第二期である「寛政時期」に入るが，この時期の美術 的中心地を京都としており, 江戸はこの時期も第一期で ある「寛永時期」の勢いに支配されているとしていた。 これより, 幕末よりも時間的には「寛永時期」に近い享 保年間を, 美術史的により高く評価していたと考えられ る。

28）しかし，このことは註 21）で述べた出張の際の意見であ るから, 出張の日時と共にこのことがモデル決定の理由 の一つであるのか, 議論の余地は大きい。

29）その一つに見学方法がある。金閣寺は三層構成であり, これをモデルとした場合には, 時代分けをした展示は上 下に積み重好る形式になり，内部に階段を設けて見学用 の動線を作らねばならず，室内に見学者を入れざるを得 ない。しかし，鳳凰堂をモデルとした場合は，三棟構成 
であるから展示は平面的に広げることができ, 見学者を 室内に入れずにすむ。事実, 㮩凰殿の見学は建物の周囲 に巡らせた縁から行わせ，室内に見学者を入れないよう にしていた。これより，見学方法という計画的な面加ら 鳳凰堂が選ばれた可能性はある。
また，鳳凰堂と金閣寺がモデル候補であった時点で日 本館の費用は決まっていたから，予算的な問題が鳳凰堂 をモデルとする理由の一つとなったことも考えうる。

(1991 年 12 月 9 日原稿受理, 1992 年 2 月 4 日採用決定) 